\title{
Default In And Credit Agreement And Implementation Of Solution Efforts (A Case Study Of Decision 336 / Pdt / G / 2016 / Pn.Smg)
}

\author{
Dhika Rachmat Pratama ${ }^{1}$ and Amin Purnawan ${ }^{2}$
}

Abstract. To be implemented lending by banks, there must be an agreement between the banks as creditors and customers as debtors called credit agreement. In providing credit to the public, the Bank must be sure that the funds lent to the community it will be returned on time, with interest and with the terms that have been agreed between the bank and the customer that have been set forth in the credit agreement. In completing this study, the authors use a step to find data and collect data either through the study of literature and other data sources and to analyze the subject and object data obtained through sosiogis juridical approach, while sampling was conducted through interviews with directional type. This study focused on the integration or coherence in the manufacture / preparation of bank loan agreement and accommodate interests of the parties in a balanced manner in the bank credit agreement. The credit agreement that accommodates the interests of the parties in a balanced manner is expected to provide benefits and fairness to the parties that lead to the achievement of the objectives of law, the object of study in this research is related to the case of default on the decision number 336 / Pdt / G / 2016 / PN.SMG that involving PT. Bank of Central Java as the plaintiff and Ir. Hj. Fatimah as a defendant.

Keywords: Banks; Credit; Default

\section{Introduction}

Lending to the public is done through a credit agreement between the recipient of the loan resulting in a legal relationship between the two. Often encountered in the field of credit agreements made by the creditor or in this case the bank, while the debtor only learn and understand. However, this agreement needs special attention from both sides due to the credit agreement has a very important function in the provision, management and management of the credit within an agreement made between the debtor to the creditor, if the debtor entered into loan agreements are considered binding on both parties and Act applies as for both. ${ }^{3}$

Implementation of lending conducted by the bank of course does not always run smoothly as desired so in the implementation, banks should be careful. Banks must be able to be wise in giving a loan or credit to the public so that in this case the bank shall observe the principles of distribution or provision of credit. The principle is the principle of trust loans, a grace period, the degree of risk, achievement / credit objects. An indicator of this is lending moral beliefs, commercial, financial, and collateral. One of the precautionary principle used by banks in providing banking credit by using the collateral in order to obtain a guarantee of debt repayment when the lender in default. In an agreement made by the State Savings Bank of Semarang also use the

\footnotetext{
${ }^{1}$ Student of Masters (S2) of Law Faculty of Law Unissula Semarang email rachmatdhika@gmail.com

${ }^{2}$ Lecturer of Faculty of Law UNISSULA Semarang

${ }^{3}$ Hermansyah 2005Hukum Perbankan Nasional Indonesia Jakarta: Prenada Media p.82
} 
precautionary principle to ensure the credit of the debtor repaid to the creditor, collateral to be used in the form of Mortgage, Mortgage collateral could include land rights set forth in the Rights Of dependents. The existence of the collateral which is set in the Mortgage function if there are debtors who break their promises or are in default of the credit agreement the bank (lender) may make the execution of Mortgage by public auction in order to meet the achievement delayed by the debtor, then in terms of the bank is also less risky when providing credit in large numbers in accordance with the goods in dependents. Mortgage guarantees could include land rights set forth in the dependents rights. The existence of the collateral which is set in the Mortgage function if there are debtors who break their promises or are in default of the credit agreement the bank (lender) may make the execution of Mortgage by public auction in order to meet the achievement delayed by the debtor, then in terms of the bank is also less risky when providing credit in large numbers in accordance with the goods in dependents. Mortgage guarantees could include land rights set forth in the Rights Of dependents. The existence of the collateral which is set in the Mortgage function if there are debtors who break their promises or are in default of the credit agreement the bank (lender) may make the execution of Mortgage by public auction in order to meet the achievement delayed by the debtor, then in terms of the bank is also less risky when providing credit in large numbers in accordance with the goods in dependents.

Mortgage is a strong security interest that can be charged to replace land rights and credietverband hypotheek institutions, according to the provisions of Article 1 paragraph 1 of Act No. 4 of 1996 on Mortgage of Land Along with objects related to the land, are: Mortgage on land and related objects with soil, hereinafter called the Mortgage, is a security interest that is charged on land rights as stipulated in Act No. 5 of 1960 on Basic Regulation of Agrarian, following or not following other objects that are installed on the ground that, for the repayment of certain debt, which gives precedence to the position of certain creditors to other creditors. ${ }^{4}$

The focus of study in this research is related to the case of default on the decision number 336 / Pdt / G / 2016 / PN.SMG involving PT. Bank of Central Java as the plaintiff and Ir. Hj. Fatimah as a defendant, in the opinion of the author terguat in this regard have committed themselves to as debtors in agreement Working Capital Business Credit (KUM) Rp. 1,500,000,000, - and Working Capital Business Credit (KUM) Futures for Rp.500.000.000, -, then as collateral under the credit agreement, attached to a piece of land next to everything that stands above it as collateral with the loan repayment agreed and signed the Deed granting Mortgage (APHT) conducted by Ir. $\mathrm{Hj}$. Fatimah as a defendant and approved by her husband. In line with the above,

Based on the background above authors are interested in writing a scientific article entitled "Default in Implementing Credit Agreement And Effort Solved (Case Study Decision 336 / Pdt / G / 2016 / PN.SMG)". This article would like to answer the question Is the root causes of defaulting on bail Mortgage Bank Semarang Central Java?

\footnotetext{
${ }^{4}$ Purwadi Patrik dan Kashadi 2001 Hukum Jaminan Semarang: Fakultas Hukum Universitas Diponegoro 2001 p. 14
} 


\section{Research Methods}

The approach used in this study is a sociological juridical approach. This approach is made to understand in the context of community law is an approach that is nondoctrinal. Through this approach, the object of the law will be interpreted as part of the social subsystem among other social subsystems. ${ }^{5}$

Legal Socio Legal Research are used in this study because in this study will be presented on the role of the Notary in the execution of the credit agreement and the settlement of the guarantee of mortgage defaults. Are analytical, because of data obtained was conducted qualitative analytical data. There are many ways to think analytically viewing the law as imposing logical linkages between rules and between the existing sections in the rule of law, any legal term used always are defined explicitly. ${ }^{6}$ Qualitative type and way of observation used as a kind of observation that starts from the workings of the descriptive, then the observation is focused and ultimately selected observation ${ }^{7}$.

This research is descriptive analysis research that illustrate or describe the applicable law relating to theories of law and a state or certain places in a factual and accurate then analyze the data obtained from the study. ${ }^{8}$ Descriptive analysis is the type of research to provide data as thoroughly as possible about a social phenomenon or phenomena that occur in the life of society by simply exposing the facts systematically, according to the needs of research. ${ }^{9}$ This analytical descriptive study can easily identify user problems (cases) linked with phenomena or other related symptoms and describes the defaults in the execution of the loan agreement and completion efforts to guarantee the security rights.

The type of data in this study using two types of data. The data collected are primary data and secondary data. The primary data obtained directly at the object studied through interviews with several sources, related to the legal analysis of the breach in the execution of the credit agreement and the efforts of its completion, the data in the study of law is a provision supporting data in the field research.

Secondary data is data obtained from the review of literature or review of against literature or library materials related to the problem or research materials that are often referred to as the legal materials include: Legal Materials Primer, in the form: the draft Civil Code, Act of the Number 10 of 1998 on Banking; While Legal Materials Secondary includes: The books on the law of treaties, books on banking, magazines academic concerning credit agreements, articles of articles relating to the credit agreement of mortgage, the Internet, and books on research methodology, and results

5 Widhi Handoko Contoh Penulisan Proses Penelitian Dalam Metode Penelitian http://widhihandoko.com/?tag=metode-penelitian-kualitatif Accessed on 31 April 2018.

${ }^{6}$ Esmi Warassih Pranata Hukum Sebuah Telaah Sosiologis (Semarang: Penerbit Alumni 2005 p.1

${ }^{7}$ Sanafiah Saisal Faisal 1990 Penelitian kualitatif : dasar-dasar \& aplikasinya Malang: Yayasan Asah Asih Asuh Malang p.80

${ }^{8}$ Soerjono Soekanto \&Sri Marmudji 1985 Penelitian Hukum Normative Suatu Tinjauan Singkat Jakarta: Raja Grafindo Persada p. 52

${ }^{9}$ Loc.Cit p. 98 
of the scientific work of scholars on the Law of Treaties and Banking, research results on the Law of Treaties and Banking. Tertiary legal materials are materials that provide information about the primary legal materials and secondary law, which consists of: Law Dictionary; Dictionaries other related fields of study of this research The collection of data is very closely related to the data source, because through this data collection will be obtained the data needed for subsequent analysis as expected. In this regard, in this study used data collection methods as follows: Primary data is data obtained directly from the public through: Interviews, namely how to obtain information by asking questions directly to the parties interviewed, especially those who are authorized, knowing and relating to the role of the Notary in the execution of the credit agreement and the settlement of the guarantee of mortgage defaults. Based on this, on top of the respondents in this study were: (1) Aris Wibowo as a Notary Public in Semarang; (2) Harsoyo, as Branch Manager of PT. Bank Semarang Central Java.

Once the data is collected, then analyzed qualitatively to achieve clarity issues to be discussed. In analyzing the data this study used qualitative analysis methods, the research procedure that produces descriptive data analysis that is what is stated by the respondent in writing or orally, and also the real behavior, who researched and studied as a whole. ${ }^{10}$

\section{Results And Discussion}

\subsection{Causes of Occurrence of Default With Mortgage Guarantee On Bank Semarang Central Java}

\subsubsection{Steps Creditors In Credit Guarantee Mortgage And Imposition Process}

The use rights to land as collateral or practiced in the provision of credit for various purposes including for the purposes of development, because the land is considered the safest as collateral. In this connection object Encumbrance UUHT determine not only the land but only following or not following other objects on the land in question which is the unity with the ground. It must be loaded firmly in the power of attorney to charge the Mortgage and the Mortgage Deed made by PPAT.

It is important for the Bank to always pay attention to and researching continuously if necessary to make a special register regarding when the rights to the land that became the object of Mortgage for the credit will expire. The goal that the Bank prior to the expiration of the right to land, it is easy to apply for an extension of the rights to the National Land Agency. To confirm the loading procedure Encumbrance, in UUHT has no provisions to include two components, supporting them through the creation of Mortgage Deed Granting by the Land Deed Official (PPAT) and is registered by the Land Office. UUHT trying to create certainty of the two components by specifying two obligations: First, PPAT obligation to send to the Land Office files which are required to register Encumbrance within 7 (seven) days after being made Deed Granting Mortgage. Secondly, the Land Office is required to include the date of granting such Encumbrance 7 (seven) days from the receipt of the complete file.

\footnotetext{
${ }^{10}$ Ibid p.250.
} 


\subsubsection{The occurrence of Credit Loss With Mortgage Guarantee On Bank Central Java city of Semarang}

Bad credit does not happen just like that, in most instances, a variety of symptoms gradually decline in credit quality occurred before the case of bad credit have emerged included the guarantee of mortgage credit, the bank jateng in this study will consider the debtor as credit problems. Nonperforming loans are the most wary in lending activities, mainly been entered in the class of non-performing loans. A credit crunch is a manifestation of a lack of awareness of the meaning of trust on the debtor's main guarantee credit facilities therefore must be accompanied by an element of trust between the bank as lender by customers as loan recipients.

In general categories of problem loans and loss can be assessed from three (3) aspects: ${ }^{11}$

- Business prospect;

- Financial condition with emphasis on cash flow;

- Ability to pay.

\subsection{Factors Occurrence of Default With Mortgage Guarantee On Bank Central Java city of Semarang}

Bad credit / defaulting on credit agreements encumbrance Bank of Central Java city of Semarang is caused by several factors that influence it, namely the factor derived from the customer and from the bank. Bank as the lender does not in spite of weaknesses, this factor does not stand alone, but always related to the customers. These factors such as: ${ }^{12}$

- The failure of the debtor's business,

- Natural disasters or the plight of the debtor,

- Misuse of credit facilities by customers,

- The decline in economic activity and high interest rates,

- Utilization competitive climate unhealthy banking world by debtors who are not responsible,

- The debtor is not able to manage the credit received, or the ability of debtor management is weak,

- Their poor faith than the debtor itself,

\section{Closing}

\subsection{Conclusion}

a. Factors causing collateral event of default by the Mortgage Bank of Central Java city of Semarang is caused by several factors, namely factor derived from the customer and from the bank. Bank as the lender does not in spite of weaknesses, this factor does not stand alone, but always related to the customers. These factors such as: 1 ) failure of the debtor's business, 2) The existence of a natural disaster or calamity

\footnotetext{
11 Author interview excerpts with Widita as Legal Reviewed 25 Partners Bank Central Java city of Semarang interview on May 222018.

12 Author interview excerpts with Widita as Legal Reviewed 25 Partners Bank Central Java city of Semarang interview on May 222018.
} 
that befell the debtor, 3) Misuse of credit facilities by customers, 4) The decline in economic activity and high interest rates, 5) Exploiting competitive climate of the banking world are not healthy by irresponsible debtor, 6) the debtor is not able to manage the credit received, or the ability of weak debtor management, 7) the existence of good faith that is less than the debtor itself.

\subsection{Sugestion}

- To the Bank as lender to be more megedepankan the precautionary principle both to obejk guarantee or to peronality debtors in the execution of the loan agreement with the guarantee of mortgage, other than that the banks also need to conduct surveillance and repression strictly to the legal who committed abuse of procedure personal interests, such as mengesampingakn important aspects in assessing debtors that because there are personal ties between the debtor and the legal as the representative of creditors.

- To the public before deciding to apply for a loan with the guarantee of the security rights to potential creditors in order to be more careful in studying the contract offered by the creditor, because the form the contract offered is standard (standrat contract) and can not be negotiable, but it is very necessary to understand the effects law that will arise when the default in the credit agreement with the guarantee of mortgage.

\section{Bibliography}

[1] Hermansyah 2005. Hukum Perbankan Nasional Indonesia Jakarta: Prenada Media

[2] Purwadi Patrik dan Kashadi 2001. Hukum Jaminan Semarang: Fakultas Hukum Universitas Diponegoro

[3] Esmi Warassih 2005. Pranata Hukum Sebuah Telaah Sosiologis Semarang: Penerbit Alumni

[4] Sanafiah Saisal Faisal 1990. Penelitian kualitatif : dasar-dasar \& aplikasinya Malang: Yayasan Asah Asih Asuh

[5] Soerjono Soekanto\&Sri Marmudji 1985. Penelitian Hukum Normative Suatu Tinjauan Singkat Jakarta: Raja Grafindo Persada

[6] Widhi Handoko Contoh Penulisan Proses Penelitian Dalam Metode Penelitian http://widhihandoko.com/?tag=metode-penelitian-kualitatif Accessed on 31 April 2018. 